\title{
DETERMINANTS OF CHRONIC ENERGY DEFICIENCY AND LOW BODY MASS INDEX OF PREGNANT WOMEN IN INDONESIA
}

\section{Determinan Kurang Energi Kronik dan Indeks Massa Tubuh Rendah pada Ibu Hamil di Indonesia}

\author{
Teti Tejayanti*
}

Center for Research and Development of Public Health Efforts

National Institute of Health Research and Development, Jakarta

*Email: teti.teja@yahoo.co.id

Naskah masuk 1 November 2019; review 19 November 2019; disetujui terbit 31 Desember 2019

\begin{abstract}
Abstrak
Latar belakang: Status gizi perempuan di Indonesia cenderung memburuk. Hasil Riset Kesehatan Dasar (Riskesdas) menunjukkan bahwa kekurangan energi kronis (KEK) pada wanita usia reproduksi meningkat dari 13,6 persen pada 2007 menjadi 20,8 persen pada 2013. Ibu hamil yang kekurangan gizi akan berdampak buruk pada bayinya.

Tujuan: Memperoleh determinan status gizi kurang yaitu KEK dan Indeks Massa Tubuh (IMT) rendah dari wanita hamil di Indonesia pada tahun 2013.

Metode: Penelitian menggunakan data Riskesdas 2013. Analisis dilakukan dengan multivariat regresi logistik. Jumlah sampel adalah 7236 ibu hamil. Ibu hamil dikatakan KEK jika pertengahan lingkar lengan atas (LILA) < $23,5 \mathrm{~cm}$ dan IMT diukur dengan pendekatan metode Broca.

Hasil: Determinan ibu hamil KEK dan IMT rendah adalah tinggal di perdesaan (AOR 1,20; 95\% CI [1,11-1,13]), usia $<20$ tahun (AOR 1,62; 95\% CI [1,60-1,65]), paritas 1 anak (AOR 2,04; $95 \%$ CI [2,02-2,06]), berpendidikan rendah (AOR 1,92; 95\% CI [0,91-0,93]) dan status ekonomi rendah (AOR 3,36; 95\% CI [3,31-3,41]).

Kesimpulan: Pendidikan harus ditingkatkan minimal hingga sekolah menengah atas sehingga pengetahuan gizi ibu meningkat dan kehamilan dini dapat dicegah. Ibu dengan status ekonomi rendah harus menjadi prioritas dalam pelayanan ibu dan upaya intervensi gizi.
\end{abstract}

Kata kunci: Sosial ekonomi, lingkar lengan atas, KEK, BMI, gizi ibu hamil.

\begin{abstract}
Background: The nutritional status of women in Indonesia tends to worsen. Basic Health Research (Riskesdas) showed that chronic energy deficiency (CED) among women of reproductive age increased from 13.6 percent in 2007 to 20.8 percent in 2013. Pregnant women who are lack of nutrition will have an impact on their babies.

Objective: To determine the determinants of poor nutritional status which are CED and low body mass index (BMI) of pregnant women in Indonesia.

Method: This study used 2013 Riskesdas data. The analysis was done using multivariate logistic regression. The total sample was 7236 pregnant women. Pregnant women with CED are those who have mid-upper arm circumference (MUAC) of less than $23.5 \mathrm{~cm}$ and BMI was measured by the Broca method approach.

Results: The determinants of pregnant women with CED and low BMI are living in rural area (AOR 1.20; $95 \%$ CI [1.11-1.13]), age of $<20$ years (AOR 1.62; 95\% CI [1.60-1.65]), having 1 child (AOR 2.04; 95\% CI [2.022.06]), having low education (AOR 1.92; 95\% CI [0.91-0.93]) and low economic status (AOR 3.36; 95\% CI [3.313.41]).

Conclusion: Education must be improved to at least high school degree, so that the mother's nutritional knowledge will increase, and early pregnancy will be prevented. Mothers with low economic status must be priority in maternal cervices and nutrition interventions.
\end{abstract}

Keywords: Socioeconomic, nutrition, mid-upper arm, CED, BMI, nutrition of pregnant women 


\section{BACKGROUND}

The nutritional status of women in Indonesia tend to deteriorate. 2007 Basic Health Research (Riskesdas) showed that chronic energy deficiency (CED) in women of reproductive age was 13.6 percent, ${ }^{1}$ whereas in 2013, the prevalence increased to 20.8 percent. $^{2}$ In pregnant women, the prevalence of CED was 24.2 percent, and it was higher among age group of $15-19$ years $(38.5 \%){ }^{2}$ World Health Organization (WHO) states that a morbidity is considered as a crucial public health condition if the prevalence is more than 15 percent. $^{2}$ CED is a picture of energy shortages in the longterm/chronic.

Short-term nutritional deficiencies which are not chronic can be assessed through weight gain. The nutritional status of pregnant women can also be assessed through maternal weight gain during pregnancy. However, this figure is sometimes difficult to obtain as preconception weight records are less reported, or initial examination is done in early pregnancy. In this regard, the assessment can be done through body mass index (BMI) approach. The 2013 Riskesdas showed that lower BMI is more common among the age group of less than 19 years $(24.5 \%)$, no schooling (20.6\%), living in rural area (11.5\%) and lowest quintile (16.4\%), compare to other groups. ${ }^{2}$

Poor nutritional status of pregnant women will have an impact on poor outcome. The CED and low BMI will lead to higher risk of infant morbidity and mortality. Both are occurred among those with poor maternal nutritional status, so this will have an impact on poor outcomes. The condition will increase the risk of premature birth, low birth weight, asphyxia, etc. Babies born in these conditions have a high chance of death. ${ }^{3}$ In the past 10 years, neonatal deaths have deliberately decreased. One of the SDG targets is that neonatal mortality rates (NMR) is no more 12 per 1000 live births. At present, NMR in Indonesia is 15 per 1000 live births. Even though the rate is approaching the target, NMR in Indonesia is still high compared to neighbour countries. ${ }^{4}$ The number of neonatal deaths is also greater, which is 4-8 times than that of maternal deaths. Therefore, neonatal deaths must not be ignored. To reduce this, information on factors that contribute to CED and low BMI is imperative.

Several previous studies mentioned that socioeconomic factors play a role in nutritional status. In fact, nutritional status is also influenced by maternal factors such as age and parity, so this variable will also be analyzed. Inequalities in health services in urban and rural areas still occur, so we also analyzed these variables. The results of this analysis will confirm whether socioeconomic factors are related to the nutritional status of pregnant women in Indonesia. The benefit obtained is to be able to guide the program in the future planning related to socioeconomic factors. Therefore, this study aims to identify the determinants of poor nutritional status (CED and low BMI) of pregnant women in Indonesia.

\section{METHOD}

This manuscript had been developed by analyzing the 2013 Basic Health Reseach (Riskesdas) which is obtained from the Ministry of Health of Republic of Indonesia. Sample was selected using multi stage method and probality proporsional to size (PPS), with census block as primary sampling unit (PSU). Total number of census block in the survey was 11,986 that allocated within 33 provinces in Indonesia. In this survey, 25 households were selected in each of census block. ${ }^{2}$

\footnotetext{
${ }^{*}$ Corresponding author

(Email: teti.teja@yahoo.co.id)

(C) National Institute of Health Research and Development ISSN: 2354-8762 (electronic); ISSN: 2087-703X (print)
} 
Total number of households participated in the survey was 294,959 households consisting of total 1,027,763 individuals (household members). Population of this study was pregnant mothers. Total number of mothers was 191,671 women, while total number of women who were currently in pregnancy during the survey was 7,629 women. Missing and outlier data were excluded in the analysis. Method of data collection was interview, anthropometry measurement and laboratory blood sample measurement. $^{2}$

Independent variables were residential areas (urban-rural), age, parity, education, and wealth quintile. Age is divided into three groups $(<20$ years, $20-35$ years and $>35$ years). Parity is divided into three categories, namely having 1 child, 2-3 children and $>3$ children. The level education is divided into high education and low education. The cut-off point for low education is those who were not attending school until the first high school, whereas high education is at least having high school degree. Economic status is defined by level of wealth quintile. Quintile 1 was the lowest economic status (the poorest) and quintile 5 was the highest economic status (the richest).

Dependent variables included maternal CED based on MUAC and BMI of pregnant mothers. Maternal CED was determined by having MUAC of less than $23.5 \mathrm{~cm}^{5,6,7}$ The 2013 Riskesdas did not include data on weight prior to pregnancy. The mother's BMI was measured by indirect method, using Broca ideal body weight and calculation of weekly fetal growth (based on William Obstetric Guidelines, Pokka II academic paper 2016). ${ }^{8}$ The guidelines showed that normal growth was $0.45 \mathrm{~g}$ per week $(0.36$ 0.45 ). Based on this guideline, it showed that the average growth development for all categories of BMI was 0.35 g per week. ${ }^{9}$ The BMI approach with formula as follows: calculation of mother body weight was (height $-\mathrm{x}$ ) + (pregnancy age $\mathrm{x} 0.35 \mathrm{~g}$ ). Whereas $\mathrm{x}$ was equal to 110 if height $>=160 \mathrm{~cm}$; $x$ equal to $105 \mathrm{~cm}$ if height $<160 \mathrm{~cm}$ and $\mathrm{x}$ equal to 100 if height $<150 \mathrm{~cm}^{10}$ The results of the BMI approach are then divided into low BMI and not BMI category.

The Statistical Package for the Social Sciences (SPSS) version 25 with a complex sample procedure was used for the analysis. Frequency distribution or percentages with $95 \%$ confidence interval were used to describe the characteristics of CED and low BMI. Data was analyzed using bivariate and multivariate logistic regression in order to produce alternative statistical model. Interaction test was applied to the model. Association between independent variables (residential areas, age, parity, education and economic status) and dependent variable, maternal CED (MUAC and body weight) was statistically measured by Chi-square test and logistic regression. The bivariate statistic test showed significant association for all the independent and dependent variables $(\mathrm{p}=0.000)$.

\section{RESULT}

The results for the socioeconomic characteristics of pregnant mothers are presented in Table 1. This analysis showed that all socioeconomic factors are significantly associated to CED and low BMI among pregnant mothers. The prevalence of CED are more common among those who live in rural areas, age of $<20$ years, only have one child, have low education and the lowest economic status (quintile 1/the poorest). The same is true for the proportion of low BMI among pregnant mothers.

In the poorest group, more than half $(56.9 \%)$ of pregnant women are having CED. The pregnant mothers age $<20$ years had CED as much as 60 percent. After having a second or third child, one third (33.9-37\%) of pregnant women still lack chronic energy (Table 1). This finding indicates that there are serious problems in the nutritional status of pregnant women.

The results of further analysis proved that all socioeconomic factors are significant with CED and low BMI. Significant factors for CED and low BMI are residence, age, parity, level of education and economic status. The highest chance of having CED and low BMI are among those in the poorest economic status (quintile 1). Pregnant women with lower economic status were 3.4 times more likely to have CED and low BMI than rich pregnant women (Table 2).

Another potential factor for CED and low BMI is parity. Mothers who have one child were 2 times more likely to have a CED and low BMI compared to mothers who have 2 or 3 children (Table 2). The third factor is education. Low educated pregnant women are 1.9 times more likely to have CED and low BMI than those with high education. The $4^{\text {th }}$ factor that 
contributes to CED and low BMI is age. Mothers who were prenant at the age of $<20$ tend to have CED and low BMI 1.6 times than those in the age group of 20-35 (Table 2).

Table 1. Association between CED, low BMI and socioeconomic status

\begin{tabular}{cccc}
\hline Maternal factors & $\begin{array}{c}\text { CED } \\
(\%)\end{array}$ & $\begin{array}{c}\text { Low BMI } \\
(\%)\end{array}$ & $\begin{array}{c}\text { P value } \\
(\%)\end{array}$ \\
\hline Residential area & 36.3 & 22.0 & 0.000 \\
Urban & 47.0 & 25.9 & \\
Rural & & & 0.000 \\
Age (years) & 60.8 & 37.5 & \\
$<$ 20 & 40.9 & 23.1 & \\
20-35 & 29.0 & 18.6 & \\
$>35$ & & & \\
Parity & 50.0 & 31.5 & \\
1 child & 33.9 & 14.2 & 0.000 \\
$>3$ children & 37.0 & 19.2 & \\
2-3 children & & & \\
Education & 38.4 & 22.7 & \\
High education & 43.3 & 24.6 & \\
Low education & & & \\
Wealth quintile & 56.9 & 36.2 & \\
Quintile 1 & 46.9 & 24.7 & \\
Quintile 2 & 42.7 & 21.7 & \\
Quintile 3 & 37.0 & & \\
Quintile 4 & 32.6 & & \\
Quintile 5 & & & \\
\hline
\end{tabular}

Table 2. Determinants of CED and low BMI among pregnant women

\begin{tabular}{|c|c|c|c|c|c|c|}
\hline \multirow{2}{*}{ Factors } & \multirow{2}{*}{$\mathrm{B}$} & \multirow{2}{*}{ S.E. } & \multirow{2}{*}{ Sig. } & \multirow{2}{*}{$\operatorname{Exp}(\mathrm{B})$} & \multicolumn{2}{|c|}{$95 \% \mathrm{CI}$ for $\mathrm{EXP}(\mathrm{B})$} \\
\hline & & & & & Lower & Upper \\
\hline \multicolumn{7}{|l|}{ Residential area } \\
\hline Rural & -0.112 & 0.004 & 0,000 & 1.118 & 1.109 & 1.127 \\
\hline Urban & & & & 1.000 & & \\
\hline \multicolumn{7}{|l|}{ Age (years) } \\
\hline$<20$ & 0.485 & 0.007 & 0,000 & 1.624 & 1.603 & 1.645 \\
\hline$>35$ & 0.165 & 0.007 & 0,000 & 0.848 & 0.836 & 0.859 \\
\hline $20-35$ & & & & 1.000 & & \\
\hline \multicolumn{7}{|l|}{ Parity } \\
\hline 1 child & 0.713 & 0.004 & 0,000 & 2.041 & 2.024 & 2.058 \\
\hline$>3$ children & -0.169 & 0.006 & 0,000 & 0.845 & 0.834 & 0.856 \\
\hline 2-3 children & & & & 1.000 & & \\
\hline \multicolumn{7}{|l|}{ Education } \\
\hline Low education & 0.086 & 0.004 & 0,000 & 1.917 & 0.909 & 0.925 \\
\hline High education & & & & 1.000 & & \\
\hline \multicolumn{7}{|l|}{ Wealth quintile } \\
\hline Quintile 1 & 1.213 & 0.007 & 0,000 & 3.362 & 3.314 & 3.411 \\
\hline Quintile 2 & 0.501 & 0.007 & 0,000 & 1.651 & 1.630 & 1.673 \\
\hline Quintile 3 & 0.328 & 0.006 & 0,000 & 1.388 & 1.372 & 1.405 \\
\hline Quintile 4 & 0.204 & 0.005 & 0,000 & 1.227 & 1.214 & 1.240 \\
\hline Quintile 5 & & & & 1.000 & & \\
\hline
\end{tabular}


Table 3 showed more detailed analysis of socioeconomic factors. The results obtained are information about gaps that occur according to the economic level. Within the age group of less than 20 years, poor pregnant women were three times more likely to have CED and low BMI than rich ones. Having many children requires readiness to well-being and care for children and can be a problem if in a state of lower economic conditions. This finding found that mothers who have many children (e.g. more than 3 children) have no difference between poor and rich mothers.

Table 3. Maternal characteristics by wealth quintile

\begin{tabular}{lcccccc}
\hline Characteristics & $\begin{array}{c}\text { Quintile } 1 \\
(\%)\end{array}$ & $\begin{array}{c}\text { Quintile } 2 \\
(\%)\end{array}$ & $\begin{array}{c}\text { Quintile } 3 \\
(\%)\end{array}$ & $\begin{array}{c}\text { Quintile } 4 \\
(\%)\end{array}$ & $\begin{array}{c}\text { Quintile 5 } \\
(\%)\end{array}$ & $\mathrm{N}$ \\
\hline Age (years) & & & & & & \\
$\quad<20$ & 19.6 & 30.3 & 27.4 & 16.8 & 6 & 513 \\
$20-35$ & 11.2 & 15.9 & 20.1 & 28.4 & 24.3 & 1084 \\
$\quad>35$ & 11.5 & 19.9 & 18.9 & 25.9 & 23.8 & 5639 \\
Parity & & & & & & \\
$\quad$ child & 10.7 & 16.6 & 21.8 & 27.5 & 23.4 & 2248 \\
$\quad \begin{array}{l}\text { 2-3 children } \\
>3 \text { children }\end{array}$ & 10.7 & 17.7 & 20.6 & 27.2 & 22.7 & 3525 \\
Education & 19.3 & 19.2 & 17.9 & 22.8 & 20.8 & 1463 \\
$\quad$ High education & 2.6 & 7.7 & 15.5 & 35 & 39.2 & 3029 \\
$\quad$ Low education & 18.7 & 24.6 & 24.3 & 21.6 & 10.9 & 4207 \\
$\quad \begin{array}{l}\text { Residential area } \\
\quad \text { Urban }\end{array}$ & & & & & & \\
$\quad$ Rural & 3.1 & 9.4 & 20.4 & 35 & 21.0 & 3402 \\
\hline Total & 22.1 & 26.9 & 20.8 & 18.2 & 12.0 & 3834 \\
\hline
\end{tabular}

Table 3 shows that education is a significant factor contributing to CED and low BMI. The results of the analysis show that within the group of pregnant women with lowest economic status (quintile 1), the likelihood of having low education was seven times than having high education. Whereas within rich group, a quarter of pregnant women tend to have low education.

The results of this study are in line with theory and other studies, because poor individuals who usually have a low level of education, are still at a young age and live in the countryside. This finding was logical as the data of this study can be interpreted quite well.

\section{DISCUSSION}

Nutritional status in pregnant women can be assessed through indicators of CED. Results of Riskesdas show that proportion of pregnant women with CED are increasing. This is a problem, because pregnant women who have malnutrition status will have an impact on their babies. These effects in the short term can cause newborn deaths. In the long term, babies born to mothers with poor nutritional status will cause infants at an adult age to risk of noncommunicable diseases, i.e. susceptible to kidney disease, diabetes and cardiovascular disease.

For this reason, this manuscript is important to obtain information on factors that cause or indirect factors that can cause CED. In addition to $\mathrm{CED}$, weight gain during pregnancy can also affect the condition of the fetus. However, records regarding weight gain are not easy to obtain, so a calculation approach is used using the estimated BMI estimated through the Broca approach. Therefore, this manuscript aims to obtain certain factors from CED and BMI.

This study has proved significant association of socioeconomic and maternal CED and low BMI. The multivariate analysis shows that economic status has the strongest association with maternal nutrition status. Mothers in poor economic status has higher CED and low BMI compared to the rich. This study compared with the results of 
previous studies. Study by Assefa on the incidence of low birth weight was associated with poverty $(\mathrm{OR}=2.1 ; 95 \% \mathrm{CI}[1.42,3.05])$, MUAC less than $23 \mathrm{~cm}(\mathrm{OR}=1.6 ; 95 \% \mathrm{CI}$ [1.19-2.19]). ${ }^{6}$ Study by Demelash et al showed that pregnant women residing in rural area (AOR $=2.1 ; 95 \%$ CI [1.04-4.33]) had socioeconomic variables associated with low birth weight. Maternal risk factors such as occurrence of health problems during pregnancy $(\mathrm{AOR}=6.3$; $95 \%$ CI [2.75-14.48]), as well as maternal BMI $<18 \mathrm{~kg} / \mathrm{m}^{2}(\mathrm{AOR}=6.7 ; 95 \% \mathrm{CI}[1.21-37.14]){ }^{11}$ The result of study by Alemu et al showed that the prevalence of low birth weight was 18 percent and significantly associated with the mothers' unemployment $(\mathrm{AOR}=5.4 ; 95 \% \mathrm{CI}$ [1.7-17.4]), residing in the rural $(\mathrm{AOR}=5.4$; 95\% CI [2.1-14.7]). ${ }^{12}$ Study by Praveen Kumar found that MUAC $<23 \mathrm{~cm}$ can detect 268 of 316 cases -84.8 percent was true positive; MUAC $<21 \mathrm{~cm}$ can detect 43 of 54 cases -79.6 percent was true positive. ${ }^{13}$ In addition to economic status, another factor related to poor nutritional status is young maternal age. Younger age (under 20 years) also gives stronger contribution to maternal CED and low BMI.

The impact and loss that will be faced by maternal CED and low BMI will be poor birth outcomes. In the short term, CED and low BMI result in babies born with low birth (LBW). Babies with LBW are at risk of asphyxia which can be the most important cause of neonatal death. In the long term, babies born in adulthood tend to have non-communicable diseases (NCD) which are currently increasing in Indonesia. Some recent literature even mentions the possibility of kidney disease. ${ }^{14,15,16,17}$ This happens because the formation of glomerulus in the kidneys does not grow optimally in malnourished mothers. In end-stage of kidney disease, the treatment is dialysis where the quality of life of patients will be severely reduced. In terms of health financing, it will drain the country's finances. This has been proven by the current national health insurance deficit because it has been burdened by a plethora of NCDs including kidney disease.

Several intervention program to address under nutrition among pregnant mother have already been developed many years ago, which include multisectoral approach. As socioeconomic status contributes to nutrition status and other health issues, it is important in directing intervention strategy towards lowering poverty, increasing education in parallel with improving healthy mother behaviour. Health intervention, such as 'love mother movement' (gerakan sayang ibu) has been developed since a decade ago in Indonesia, need to be accelerated and intensified for more effective practice to improve maternal nutrition status in all districts in Indonesia. ${ }^{18}$

Even though maternal compassionate movement programs have been carried out, and supplementary feeding program (PMT/Pemberian Makanan Tambahan) for pregnant women to improve the health of pregnant women, but these efforts have not had enough impact. The reason is that in pregnant women with lower education, lower economic status is not optimal or become priority in getting information and PMT intervention. This can be seen from the wide gap between vulnerable and rich groups. Findings from Sara showed that groups with poor nutritional status are found in low-status economic groups more than the rich. ${ }^{19}$ Status of anemia is found more often in mothers with poor economic levels compared to the rich. ${ }^{20}$ Finding of Demographic Heath Survey di Nigeria 2015 showed that gaps in socioeconomic and sociodemographic are related with nutrition. ${ }^{21}$

\section{CONCLUSION}

Non-health factors such as low economic, low education and young adult $(<20$ years old $)$ pregnancy contribute to lack of nutritional. The factors were significant to CED and low BMI among women in rural area, age $<20$ years, parity of one child, having low education, and lower economic status.

\section{RECOMMENDATION}

Education must be improved to at least high school degree, so that the mother's nutritional knowledge increases and prevents early pregnancy. Both government and nongovernmental sectors should be able to conduct more effective advocacy to multisector particularly to education, family planning, women empowerment, and other related sectors. Intervention strategy need to be directed towards providing supportive regulation on female minimum age of married 
that are older than 20 years old. Pregnant women who experienced CED and low BMI must be intervened by providing information on the importance of nutrition so that the baby is born with normal birthweight. Policy and regulation should be directed towards 12-year compulsory education and/higher education institutions need to actively promote women's education as well as lowering the impact of poverty on the rural women population. Women with poor economic status must be priority in maternal services and nutrition interventions.

\section{ACKNOWLEDGEMENT}

High appreciation and gratitude are expressed to the Head of National Institute of Health Research and Development, Ministry of Health for the opportunity to use 2013 Riskesdas. Author gives special thanks to Trihono, consultant from the Health Policy Unit, Nunik Kusumawardani, and Olwin Nainggolan for their support in providing the Riskesdas data and Atmarita Tilden for her inputs in maternal nutrition and health issues. Author also thanks to Edo which has helped the citation process.

\section{REFERENCES}

1. National Institute of Health Research and Development. Basic Health Research 2007. Jakarta, Indonesia; 2007.

2. National Institute of Health Research and Development. Basic Health Research 2013. Jakarta, Indonesia; 2013.

3. Behrman RE SBA. Committee on Understanding Premature Birth and Assuring Healthy Outcomes Board on Health Sciences Policy P R ETE R M B I RTH Library of Congress Cataloging-inPublication Data [Internet]. Preterm Birth: Causes, Consequences, and Prevention. 2007.

4. Anonim. ASEAN Statistic Leaflet_Selected Key Indicator. 2017.

5. Tang AM, Chung M, Dong K, Terrin N, Edmonds A, Assefa N, et al. Determining a Global Mid-Upper Arm Circumference Cutoff to Assess Malnutrition in Pregnant Women. Food Nutr Tech Assictance III Proj. 2016;(June):76.
6. Assefa N, Berhane Y, Worku A. Wealth status, mid upper arm circumference (MUAC) and Ante Natal Care (ANC) are determinants for low birth weight in Kersa, Ethiopia. PLoS One. 2012 Jun;7(6).

7. Kementerian Kesehatan. Standard Antropometri Penilaian Status Gizi Ibu Hamil dan Menyusui. Naskah Aka. Jakarta, Indonesia; 2016.

8. William Obstetric. Guidelines of obstetric gain and pregnancy '24th. IOM, NRC; 2016.

9. Arali. Menghitung Berat Badan Ideal Ibu Hamil. 2009;

10. UkuranDanSatuan.Com. Cara Menghitung Berat Badan Ideal dengan Rumus Broca. UkuranDanSatuan.Com.

11. Demelash H, Motbainor A, Nigatu D, Gashaw K, Melese A. Risk factors for low birth weight in Bale zone hospitals, SouthEast Ethiopia : A case-control study. BMC Pregnancy Childbirth. 2015 Oct;15(1).

12. Alemu A, Abageda M, Assefa B, Melaku G. Low birth weight: Prevalence and associated factors among newborns at hospitals in kambata-tembaro zone, southern Ethiopia 2018. Pan Afr Med J. $2019 ; 34$.

13. Praveen Kumar et al. Screening Maternal Acute Malnutrition Using Adult Mid-Upper Arm Circumference in Resource-Poor Settings. Indian J Community Med. 2018;43(2)(1):132-134.

14. Watkins AJ, Lucas ES, Torrens C, Cleal JK, Green L, Osmond C, et al. Maternal lowprotein diet during mouse pre-implantation development induces vascular dysfunction and altered renin-angiotensin-system homeostasis in the offspring. Br $\mathrm{J}$ Nutr. 2010 Jun;103(12):1762-70.

15. Mesquita FF, Gontijo JAR, Boer PA. Maternal undernutrition and the offspring kidney: From fetal to adult life. Brazilian J Med Biol Res. 2010 Nov;43(11):1010-8.

16. Lloyd LJ, Foster T, Rhodes P, Rhind SM, Gardner DS. Protein-energy malnutrition during early gestation in sheep blunts fetal renal vascular and nephron development and compromises adult renal function. J Physiol. 2012 Jan;590(2):377-93. 
17. Dunford LJ, Sinclair KD, Kwong WY, Sturrock C, Clifford BL, Giles TC, et al. Maternal protein-energy malnutrition during early pregnancy in sheep impacts the fetal ornithine cycle to reduce fetal kidney microvascular development. FASEB J. 2014;28(11):4880-92.

18. Repository DM. Gerakan Sayang Ibu Hamil ( Gesib ) Melalui Pemberian Pendidikan Kesehatan , Pemberian Paket Makanan Tambahan Berbahan Dasar Lokal dan Pemberdayaan Masyarakat di Desa Sucopangepok Kecamatan Jelbuk-Jember ( Images of Previous Mothers through Health Educatio. 2018.
19. Herlina Sara. Hubungan status gizi dalam kehamilan dengan status ekonomi. JOMIS (JOURNAL MIDWIFERY Sci. 2017; Vol.1, No.

20. Mariza Ana. Hubungan Pendidikan Dan Sosial Ekonomi Dengan Kejadian Anemia Pada Ibu Hamil Di Bps T Yohan Way Halim Bandar Lampung. ) J Kesehat HOLISTIK. 2016; Vol 10, No:5-8.

21. Dahlui M, Azahar N, Oche OM, Aziz NA. Risk factors for low birth weight in Nigeria: Evidence from the 2013 Nigeria Demographic and Health Survey. Glob Health Action. 2016;9(1). 